\title{
Detection of Helicobacter pylori in gastric biopsies, saliva and dental plaques of dyspeptic patients from Marília, São Paulo, Brazil: presence of vacA and cagA genes
}

Rasmussen LT (1), de Labio RW (2), Neto AC (2), Silva LC (3), Queiroz VF (4), Smith MAC (5), Payão SLM $(1,2)$

(1) Postgraduate Program in Oral Biology, Sacred Heart University, Bauru, São Paulo State, Brazil; (2) Department of Genetics, FAMEMA Blood Center, Marília Medical School (FAMEMA), Marília, São Paulo State, Brazil; (3) Department of Anatomic Pathology, Marília Medical School (FAMEMA), Marília, São Paulo State, Brazil; (4) Department of Digestive System Surgery, Marília Medical School (FAMEMA), Marília, São Paulo State, Brazil; (5) Department of Morphology, Federal University of São Paulo (UNIFESP), São Paulo, São Paulo State, Brazil.

\begin{abstract}
Helicobacter pylori, a gram-negative bacterium, possesses two important virulence factors: the vacuolating toxin $(\operatorname{vac} A)$, and the cytotoxin-associated gene product $(\operatorname{cag} A)$. The aim of the present study was to evaluate the presence of $H$. pylori in the stomach and oral cavity of humans and compare the cagA and vacA genotypes of $H$. pylori found in different samples (stomach, saliva and dental plaque) from the same patient. Gastric biopsies, saliva and dental plaques were obtained from 62 dyspeptic adults. DNA was extracted and evaluated for the presence of $H$. pylori and the alleles cagA and vacA. Persons with gastritis had a higher frequency of $\mathrm{H}$. pylori-positive samples in the stomach while positive samples from gastric biopsies were significantly correlated with those from the oral cavity. There was a high $\mathrm{H}$. pylori frequency in patients while the cagA gene was associated with vacA s1 alleles in gastric biopsies. Our results suggest a reservoir of the species in the oral cavity and that, in one patient, more than one $H$. pylori strain may exist in the saliva, dental plaque and stomach. We found a relationship between gastric infection and the bacterium in the oral cavity, with the cytotoxin genotype varying between saliva and dental plaque.
\end{abstract}

Key words: Helicobacter pylori, cagA, vacA, dental plaque, dyspeptic patient, saliva.

\section{INTRODUCTION}

Helicobacter pylori is a spiral-shaped gramnegative flagellate bacterium that has been implicated as a major human gastric pathogen responsible for gastritis and peptic ulcer disease (1). It is estimated that in developing countries like Brazil, the prevalence of $H$. pylori infection approaches $80 \%$ in adults versus 30 to $70 \%$ in developed countries (2-7).

The high prevalence of the disease has propelled an extensive search for $H$. pylori virulence factors. This research has led to the characterization of a vacuolating cytotoxin $\mathrm{A}$ (vacA) and an associated cytotoxin A ( $\operatorname{cag} A)$. The $v a c A$ gene is present in all $H$. pylori strains, and comprises two main regions that show significant sequence variability between strains: the signal region (s1 or s2) and the middle region ( $\mathrm{m} 1$ or $\mathrm{m} 2$ ). These two parts of vacA gene determine cytotoxin production and are associated with pathogenicity of the bacterium. The vacA s1/m1 allelic combination exhibits the highest activity, while $s 2 / \mathrm{m} 2$ and the rare $\mathrm{s} 2 / \mathrm{m} 1$ combinations may be less toxic (8). The vacA protein induces vacuolation and apoptotic processes in epithelial cells, as well as immunosuppressive effects in immunological cells (9).

The cag $A$ gene, present in approximately 60 to $70 \%$ of $H$. pylori strains, is located within a 40-kilobase DNA fragment known as the cag pathogenicity island (cag PAI). Several epidemiological studies have revealed that the presence of cagA-positive strains is correlated with a higher risk of developing peptic ulceration, gastric atrophy and gastric cancer 
(10). In particular, most strains of $H$. pylori carrying the $\operatorname{vac} A$ alleles $s 1 / \mathrm{m} 1$ and $\operatorname{cag} A$ have been isolated from patients with severe gastric diseases, including duodenal and gastric ulcers, gastric adenocarcinoma, and mucosa-associated lymphoid tissue (MALT) lymphoma (11-13).

In addition to the genetic aspect of $H$. pylori, Nahar et al. (14) suggested that low socioeconomic status, crowded living condition, unfavorable dietary habits and poor personal hygiene may be associated with $H$. pylori infection. Although many aspects of the epidemiology of $H$. pylori infection are known, the modes of acquisition and transmission remain unclear; however, fecaloral, oral-oral, and gastro-oral routes have been most often considered (15).

Some authors have reported the presence of $H$. pylori in the oral cavity, potentially representing a source of $H$. pylori for gastric reinfection after therapy (16). This possibility was supported by Miyabayashi et al. (17) who confirmed the relationship between gastritis induced by $H$. pylori infection and oral colonization of the bacterium, besides trying to clarify the resistance mechanisms of oral $H$. pylori to typically triple anti-H. pylori therapy employed to eradicate the pathogen from the stomach. They reported that patients with oral $H$. pylori presented a significantly elevated gastric reinfection risk following successful therapy.

Rasmussen et al. (18) suggested a relationship between gastric infection and the presence of this bacterium in the oral cavity. Despite this, $H$. pylori was present in the oral cavity with variable distribution between saliva and dental plaques, suggesting the existence of a reservoir for the species and a potential association with gastric reinfection.

Dental plaque and saliva constitute a potential reservoir for infectious microorganisms and have been shown to harbor at least 400 different types of bacteria, including H. pylori (19). However, the detection and comparison of the presence of the cagA gene and vacA alelles of $H$. pylori in dental plaque, saliva and the stomach has not been thoroughly evaluated.

The purpose of this study was evaluate the presence of $H$. pylori in the stomach and oral cavity of patients with gastritis and to compare cagA and vacA genotypes of $H$. pylori among dental plaque, saliva and the stomach in the same patients, in an attempt to elucidate the infection mechanisms of $H$. pylori and verify its possible transmission route.

\section{MATERIALS AND METHODS}

\section{Patients and Collection of Biological Samples}

Sixty-two patients (27 males and 35 females with a mean age 52.56 years) presenting with recurrent abdominal pain participated in the study. All subjects were recruited from the Ambulatory Endoscopy Unit of Marília Medical School, São Paulo, Brazil.

All individuals signed an informed consent in order to be included in the study and the local ethics committee approved the study.

Three biopsies of the gastric antrum were collected during gastroscopy. One of the specimens was used for the rapid urease test, the second for histological examination and the other for the molecular analysis. The endoscopic forceps were sterilized in $2 \%$ glutaraldehyde solution for a minimum of 20 minutes between each pair of experimental procedures. Saliva and plaque samples were collected prior to the endoscopic examination of each subject. Salivary flow was selfstimulated by each patient and $3 \mathrm{~mL}$ of saliva was collected in test tubes. Multiple samples of dental plaque from different sites throughout the oral cavity (incisors, canines, premolars and molars) were taken from each subject with a sterile curette and transferred to a test tube containing $15 \mathrm{~mL}$ of PBS (phosphate-buffered saline) $\mathrm{pH}$ 7.4.

It is worth mentioning that our group recently published a study suggesting a possible relationship between the presence of $H$. pylori in the oral cavity and the stomach (18). The authors would like to emphasize that the present study is a more detailed analysis than the previous one and aims to elucidate the genetic diversity of $H$. pylori in humans using the same samples.

\section{DNA Isolation and Preparation of DNA Probe}

DNA from the gastric biopsies was extracted using the QIAamp ${ }^{\oplus}$ tissue kit (Qiagen, Germany), according to the manufacturer's instructions. DNA extraction from the dental plaques and saliva were performed by the method of Rasmussen et al. (18) as previously described $(16,20)$. The probe was synthesized using the Gene Images AlkPhos Direct Labelling kit (GE Healthcare, UK), according to the manufacturer's instructions and the description of Rasmussen et al. (18). 
Identification of Helicobacter pylori by Urease Test, Histological and Molecular Analysis

An antral biopsy from each patient was incubated in premade broth (TUPF; Laborclin, Brazil) for the urease test (RUT) immediately after collection. The test was considered $H$. pyloripositive when the color of the solution changed from yellow to orange, pink, or purple within four hours of incubation at $25^{\circ} \mathrm{C}$.

The biopsies for the histological examination were fixed in formalin and stained with $\mathrm{HE}$ (hematoxylin and eosin) and Giemsa. The histological parameters were graded using the criteria described in the Sydney system for analysis of chronic inflammation, polymorphonuclear activity and intestinal metaplasia (21).

PCR assays were performed with approximately $100 \mathrm{ng}$ of total DNA using one set of oligonucleotides ( $\mathrm{Hpx} 1 / \mathrm{Hpx} 2)$ $\left(5^{3}\right.$-CTGGAGARACTAAGYCCTCC- ${ }^{3}$ and ${ }^{5}$-GAGGAATACTCATTGCGAAGGCGA- ${ }^{3}$ ) that amplifies a 150-bp fragment corresponding to 16S-rRNA from $H$. pylori. The cycling program was initiated with a denaturation step of $94^{\circ} \mathrm{C}$ for five minutes followed by 40 cycles at $94^{\circ} \mathrm{C}$ for one minute, $59^{\circ} \mathrm{C}$ for one minute, $72^{\circ} \mathrm{C}$ for one minute, followed by a final incubation at $72^{\circ} \mathrm{C}$ for seven minutes (22). In each experiment, positive (strain 26695) and negative (water) controls were included. After separation with electrophoresis in $2 \%$ agarose gels, PCR products were blotted to a Hybond N+ membrane and hybridized with the specific PCR fragments labeled by chemiluminescence (GE Healthcare, UK). The assay was considered positive when the PCR product was present.

\section{Detection of vacA and cagA Gene}

The vacA gene, " $\mathrm{s}$ " and " $\mathrm{m}$ " region genotyping and cagA gene detection were performed by PCR and Southern blotting, using one set of oligonucleotides for each gene fragment. For cagA detection, the previously described primers Cag1/ Cag2 (5)-ATGACTAACGAAACTATTGATC- ${ }^{3}$ and ${ }^{\prime}$-CAGGATTTTTGATCGCTTTATT- ${ }^{3}$ ) amplified 232 fragments (23). The vacA "s" and " $m$ " regions were genotyped with the previously described primer sets SA/SC $\left(5^{3}\right.$-ATGGAAATACAACAAACACAC- ${ }^{3}$ and $5^{5}$-CCTGARACCGTTCCTACAGC- ${ }^{3}$ ), and MA/ MB (5 ${ }^{3}$-CACAGCCACTTTYAATAACGA- ${ }^{3}$ and ${ }^{5}$-CGTCAAAATAATTCCAAGGG ${ }^{-{ }^{3}}$ ), respectively (23-25). The SA/SC primers amplified "s1" fragments of $176 \mathrm{bp}$ and "s2" fragments of $203 \mathrm{bp}$. The " $\mathrm{m} 1$ " fragments were $400 \mathrm{bp}$ and " $\mathrm{m} 2$ " fragments $475 \mathrm{bp}$ (23-25). The same amplification condition was used for every gene. The cycling program was initiated with a denaturation step of five minutes at $94^{\circ} \mathrm{C}$, followed by 40 cycles of $94^{\circ} \mathrm{C}$ for one minute, $53^{\circ} \mathrm{C}$ for one minute, $72^{\circ} \mathrm{C}$ for one minute, followed by a final incubation at $72^{\circ} \mathrm{C}$ for seven minutes.

\section{Statistical Analysis}

The chi-square, Fisher's exact and Kappa tests were used to analyze differences in the prevalence and cytotoxin genotypes of $H$. pylori in gastric biopsies, saliva and dental plaque samples. The significance level was set at $\mathrm{p}<0.05$.

Statistical analyses were performed using the statistical package SPSS 11.5.1 (USA).

\section{RESULTS}

Detection of Helicobacter pylori in Gastric Biopsies, Saliva and Dental Plaque by Urease, Histological and Molecular Analysis

H. pylori was detected in antral biopsies in 50/62 (80.6\%) patients via PCR and hybridization by Southern blotting. The histological analysis revealed the presence of $H$. pylori in only 19 subjects $(30.6 \%)$ whereas the urease test detected H. pylori infection in 27 patients $(43.5 \%)$. All the samples in which the histology and urease test demonstrated the presence of $H$. pylori were also positive by PCR and Southern blot hybridization. The detection of $H$. pylori in gastric antrum samples was significantly higher when the Southern blotting technique was used as compared to the histological or urease tests (chi-square $-\mathrm{p}=0.0001$ ).

The histology of $45(72.6 \%)$ patients revealed chronic gastritis while 17 (27.4\%) had normal gastric mucosa. Of the former, 41 (91\%) were found $H$. pylori-positive by PCR and Southern blot hybridization.

H. pylori was found in the saliva of 26 (41.9\%) and in the dental plaque of 29 (46.7\%) patients (Table 1). The oral cavity was operationally defined as positive when the saliva or dental plaque was positive for $H$. pylori. Sixteen patients presented with $H$. pylori confined to the stomach, while $H$. pylori DNA was concurrently detected in the gastric biopsy, saliva and dental plaques of 
Table 1. Southern blotting detection of H. pylori DNA and cagA and vacA genes in H. pylori from gastric biopsies, saliva and dental plaque

\begin{tabular}{|c|c|c|c|c|c|c|c|c|}
\hline \multirow{2}{*}{ Samples } & \multirow{2}{*}{$\mathrm{n}$} & \multirow{2}{*}{ H. pylori + } & \multirow{2}{*}{$\operatorname{cagA}+$} & \multicolumn{5}{|c|}{ vacA } \\
\hline & & & & $\mathrm{m} 1$ & $\mathrm{~m} 2$ & s1 & s2 & $s 1 / s 2$ \\
\hline Gastric biopsies & 62 & 50 & *36 & $* 28$ & 22 & *38 & 12 & - \\
\hline Saliva & 62 & 26 & 13 & - & - & 14 & 8 & 4 \\
\hline Dental plaque & 62 & 29 & 7 & - & - & 14 & 8 & 7 \\
\hline
\end{tabular}

$\mathrm{n}$ : number of individuals; * $\mathrm{p}<0.0001$

ten patients. Twenty-four subjects harbored $H$. pylori in gastric biopsies and the oral cavity. $H$. pylori DNA was not detected in 12 gastric biopsy samples, but six of these 12 cases were found to have $H$. pylori in the oral cavity.

No statistically significant difference was observed between strains in the saliva and dental plaque (chi-square $=p<0.58$ ). Despite this, a statistically significant difference was observed between gastric biopsies and the oral cavity (chisquare $=\mathrm{p}<0.0001)$.

Detection of cagA and vacA Alleles of Helicobacter pylori Isolates from Gastric Biopsies, Saliva and Dental Plaque

We isolated 25 strains of the common vacA genotype $\mathrm{s} 1 / \mathrm{m} 1$ and only 12 strains of vacA s $2 /$ $\mathrm{m} 2$. Twenty percent (ten strains) of the $H$. pylori bacterium were found to have vacA genotype $\mathrm{s} 1 / \mathrm{m} 2$, and three strains showed $v a c A$ genotype $\mathrm{s} 1 / \mathrm{m} 1 / \mathrm{m} 2$, suggesting a coinfection with two different $H$. pylori strains. The cagA gene was detected in 36 patients infected with $H$. pylori. Of these 36,32 were associated with the toxinproducing vacA s1 and can be associated with chronic gastritis while only four cagA-positive strains were vacA s2 $(\mathrm{p}<0.0001)$.

The cag $A$ gene was detected in 13 saliva samples. Of the 13 patients who were $\operatorname{cag} A$ positive, seven were associated with vacA s1, two were found to be vacA s2 and four were s1/s2. The middle region ( $\mathrm{m} 1$ or $\mathrm{m} 2$ ) of the $v a c A$ gene was genotyped only in $H$. pylori gastric isolates. The middle region of vacA was not detected in $H$. pylori isolates from these samples, which is likely related to the heterogeneity in the vacA gene as previously described $(8,10)$.

From patients with positive dental plaque, only seven of 29 strains had the cagA gene and three were associated with the toxin-producing $\operatorname{vac} A$ s1. However, 11 of the patients with cagA-negative samples demonstrated the vacA genotypes s1.

When associated with positivity for $H$. pylori, the presence of $\operatorname{cag} A$ and $v a c A$ genes and their alleles, there was approximately $85 \%$ disagreement among the three materials, just five patients showed the same genetic profile, according to the genes analyzed, in the oral cavity and biopsies, highlighting a wide variety of strains, a mixed colonization in the same host with an unequal distribution, independent of gastric biopsy, saliva or dental plaque. No statistically significant relationship was found between the presence of cag $A$ and vacA alelles in saliva or dental plaques. However, there was a statistically significant relationship between the presence of $\operatorname{cag} A$ and $v a c A$ genotypes $\mathrm{s} 1 / \mathrm{m} 1$ (Fisher $=\mathrm{p}<0.001)$. The association between the presence of cagA and vacA alleles in all strains is described in Table 1.

\section{DISCUSSION}

Our methodologies of using PCR in concordance with Southern blotting are supported by Li et al. (26) and Song et al. (27) who found a significant increase in sensitivity after incorporating the Southern blotting technique. The high sensitivity and specificity of the PCR test with Southern blotting and hybridization in our study did not reveal false positives, false negatives or contamination. This is attributed to the fact that the probe was synthesized from genomic DNA of $H$. pylori culture by PCR, which excludes false results $(28,29)$. In addition, we used more amplification cycles, optimized buffers and conditions while all $H$. pylori-positive samples were genotyped to confirm the presence of H. pylori. 
Out of 62 samples, H. pylori was detected in 50 of the gastric biopsies in which the most virulent vacA genotype $\mathrm{s} 1 / \mathrm{m} 1$ was most common. The cagA gene was detected in $72 \%$ of our patients, a level comparable to two other studies of Brazilian patients where, respectively, $70 \%$ and $79 \%$ of samples were found to be cagA-positive $(3,30)$. Several studies have described the associations between $\mathrm{s} 2 / \mathrm{m} 2$ and cagA-negative strains and between $\mathrm{s} 1 / \mathrm{m} 1$ and cagA-positive strains, both supported by the results of the present study.

Twenty-three and 31 biopsies that were positive as determined by the Southern blotting method were negative when analyzed with the RUT and histological analysis, respectively. This is expected because the sensitivity of the Southern blotting technique is much greater for the detection of $H$. pylori when compared to the RUT and histological analyses. In addition to reduced sensitivity, the histological analysis may be biased by the subjectivity of the assessment, inter-observer variation or human error (21). Researchers and clinicians should be aware of these potentially serious limitations when using histological analysis. The observation of de Francesco et al. (31) of H. pylori in 20\% of histology-negative biopsies by PCR is similar to our findings. This increased the prevalence of the pathogen from 43 to $58 \%$ in their patient samples.

In the oral cavity, $H$. pylori had been demonstrated earlier, although the exact time course of the infection is not fully elucidated. It is not clear whether the oral cavity is a permanent or a temporary reservoir for this microorganism. In our study $26(41.9 \%)$ and $29(46.7 \%)$ of the patients had $H$. pylori in saliva and dental plaque, respectively.

Li et al. (26) verified $75 \%$ positivity among saliva specimens, similar to the findings of Wang et al. (32), who found the bacterium in $71 \%$ of the saliva samples in their study. Al Asqah et al. (33) also found a significant association between the presence of $H$. pylor $i$ in the stomach and in dental plaque. In a study of 120 dyspeptic patients, $H$. pylori was detected in all of the samples from gastric biopsies and saliva (34). The results of the present study, along with the previous work, suggest that saliva may serve as a method of infection transmission and may also lead to gastric re-infection after treatment of the disease.

Some studies have suggested that the detection of $H$. pylori in saliva and dental plaque by PCR may reflect the secretion of dead bacteria from the digestive tract. However, the fact that six patients in the current study produced gastric biopsies negative for $H$. pylori by PCR and Southern blotting while testing positive for $H$. pylori in their oral cavity corroborates the hypothesis that the mouth may be a natural reservoir of $H$. pylori.

Berroteran et al. (35) also reported that $H$. pylori was detected in the oral cavity of five patients whose gastric biopsies were negative for $H$. pylori by PCR whereas $H$. pylori was also present in $15 \%$ of (three of 20) asymptomatic subjects. Li et al. (36) suggest that this phenomenon may occur because $H$. pylori may persist in low numbers in the oral cavity for many months or years without colonizing the stomach or because the oral cavity is the initial site of infection.

The vacA s1 alelle was found in 53\% of the $H$. pylori isolates from saliva and $48 \%$ of those from dental plaque, while the cagA gene was detected in $13(50 \%)$ saliva samples and only 7 (24.1\%) dental plaque samples. Unlike the gastric biopsy samples, no association was found between vacA s1 alleles and the presence of cagA gene in saliva or dental plaque samples. We detected four saliva and seven dental plaque samples with $v a c A$ alelles s1 and s2 simultaneously, suggesting the presence of multiple $H$. pylori strains in the oral cavity of the same subject. Wang et al. (32) found that the cagA gene was present in $23 \%$ of the saliva samples whereas the $v a c A$ s1 allele was present in $77 \%$ of the saliva samples. We found the cagA gene was highly prevalent in the saliva samples from our subject pool, but the prevalence of the gene was only $23 \%$ in the dental plaques. In all, approximately $70 \%$ of the oral-cavity samples were positive; however, there was a distinct difference between such positivity in saliva and dental plaques.

We also found significant genotypic diversity among $H$. pylori cytotoxins from the stomach, saliva and dental plaque samples, which corroborates the work of Wang et al. (32). The heterogeneity of $H$. pylori may be due to genotypic variation among strains and or variations in $H$. pylori populations within an individual host, as proposed by Blaser (37).

In the present study we verified that the strains found in the stomach are apparently more virulent than those in the oral cavity, an observation not explored in the literature. Thus, we can suggest that 
this selection is attributable to two explanations: $H$. pylori cagA + and "s1" have efficient adaptive mechanisms, which allow a rapid and effective colonization of the stomach, thus inhibiting the growth of less adapted organisms and suggesting a possible biological interaction called amensalism among different strains of $H$. pylori. The second explanation may be that the oral cavity can harbor at least 400 different types of bacteria and, given such bacterial heterogeneity, the adaptive mechanisms might not be efficient, thus allowing the growth of other $H$. pylori strains.

The frequency of $H$. pylori in the oral cavity differed in relation to previous studies. The difference in the presence of the pathogen in the oral cavity may be the result of differences in study populations, oral health status, clinical presence of $H$. pylori infection, the type and number of clinical samples, complexity of the oral flora or detection methods (38). Kignel et al. (16) reported that the levels of the bacterium in the oral cavity may be too low to be detected by one round of PCR and they emphasized that the region of the mouth from which the samples are collected can influence the prevalence of the microorganism. Song et al. (27) determined that the presence of $H$. pylori was $82 \%$ in the molar region, $64 \%$ in pre-molar region and 59\% in the incisor region. Loster et al. (39), suggested that this discrepancy may be attributable to the fact that the dental plaque in the posterior region of the oral cavity is less oxygenated, thus providing optimal conditions for the survival of $H$. pylori.

\section{CONCLUSION}

In summary, there is a high prevalence of $H$. pylori and the main virulence factor genes in Brazilian $H$. pylori isolates, namely the cagA gene, appears to be associated with vacA s1 alleles in gastric biopsies. Our results suggest a correlation between gastric infection and the presence of the bacterium in the oral cavity. However, $H$. pylori was present in the oral cavity with variable cytotoxin genotype cagA and $v a c A$ alleles; furthermore, there was a variable distribution between saliva and dental plaque, suggesting the existence of a reservoir of the species, which can lead to gastric re-infection. Additionally, more than one $H$. pylori strain may exist in the saliva, dental plaque and stomach of the same patient.

\section{ACKNOWLEDGEMENTS}

The authors would like to thank the Coordination for the Improvement of Higher Education Personnel (CAPES), Sacred Heart University (USC), Marília Medical School (FAMEMA) and The State of São Paulo Research Foundation (FAPESP) for their support.

\section{COPYRIGHT \\ (C) CEVAP 2012}

\section{SUBMISSION STATUS}

Received: October 4, 2011.

Accepted: November 30, 2011.

Abstract published online: January 18, 2012.

Full paper published online: May 31, 2012.

\section{CONFLICTS OF INTEREST}

The authors declare no conflicts of interest.

\section{FINANCIAL SOURCE}

The State of São Paulo Research Foundation (FAPESP) provided the financial grants (process n. 06/60836-1).

\section{ETHICS COMMITTEE APPROVAL}

The present study was approved by the Ethics Research Committee of Sacred Heart University (process n. 056/2005). Moreover, all study subjects signed an informed consent in order to be included in the study.

\section{CORRESPONDENCE TO}

Spencer Luiz Marques Payão, Laboratório de Genética, Hemocentro, FAMEMA, Rua Lourival Freire, 240, Bairro Fragata, CEP 17519-050, Marília, SP, Brasil. Phone: +55 14 34021856. Fax: +55 14 34330148. Email: slmpayao@famema.br.

\section{REFERENCES}

1. Cover TL, Blaser MJ. Helicobacter pylori in health and disease. Gastroenterology. 2009;136(6):1863-73.

2. Souto FJ, Fontes CJ, Rocha GA, de Oliveira AM, Mendes EN, Queiroz DM. Prevalence of Helicobacter pylori infection in a rural area of the state of Mato Grosso, Brazil. Mem Inst Oswaldo Cruz. 1998;93(2):171-4.

3. Brito CA, Silva LM, Juca N, Leal NC, de Souza W, Queiroz D, et al. Prevalence of cagA and vacA genes in isolates from patients with Helicobacter pylori-associated gastroduodenal diseases in Recife, Pernambuco, Brazil. Mem Inst Oswaldo Cruz. 2003;98(6):817-21.

4. Mitchell A, Silva TM, Barrett LJ, Lima AA, Guerrant 
RL. Age-specific Helicobacter pylori seropositivity rates of children in an impoverished urban area of northeast Brazil. J Clin Microbiol. 2003;41(3):1326-8.

5. Tseng FC, Brown EE, Maiese EM, Yeager M, Welch R, Gold BD, et al. Polymorphisms in cytokine genes and risk of Helicobacter pylori infection among Jamaican children. Helicobacter. 2006;11(5):425-30.

6. Yamaoka Y. Roles of the plasticity regions of Helicobacter pylori in gastroduodenal pathogenesis. J Med Microbiol. 2008;57(5):545-53.

7. Tan VP, Wong BC. Helicobacter pylori and gastritis: Untangling a complex relationship 27 years on. J Gastroenterol Hepatol. 2011;26(Suppl1):42-5.

8. Atherton JC, Cao P, Peek RM, Jr, Tummuru MK, Blaser MJ, Cover TL. Mosaicism in vacuolating cytotoxin alleles of Helicobacter pylori. Association of specific vacA types with cytotoxin production and peptic ulceration. J Biol Chem. 1995;270(30):17771-7.

9. Gebert B, Fischer W, Haas R. The Helicobacter pylori vacuolating cytotoxin: from cellular vacuolation to immunosuppressive activities. Rev Physiol Biochem Pharmacol. 2004;152(1):205-20.

10. Correa P, Piazuelo MB, Wilson KT. Pathology of gastric intestinal metaplasia: clinical implications. Am J Gastroenterol. 2010;105(3):493-8.

11. Tummuru MK, Cover TL, Blaser MJ. Cloning and expression of a high-molecular-mass major antigen of Helicobacter pylori: evidence of linkage to cytotoxin production. Infect Immun. 1993;61(5):1799-809.

12. Covacci A, Censini S, Bugnoli M, Petracca R, Burroni D, Macchia G, et al. Molecular characterization of the $128-\mathrm{kDa}$ immunodominant antigen of Helicobacter pylori associated with cytotoxicity and duodenal ulcer. Proc Nat Acad Sci USA. 1993;90(12):5791-5.

13. Yakoob J, Jafri W, Abbas Z, Abid S, Khan R, Jafri N, et al. Low prevalence of the intact cag pathogenicity island in clinical isolates of Helicobacter pylori in Karachi, Pakistan. Br J Biomed Sci. 2009;66(3):137-42.

14. Nahar S, Kibria KM, Hossain ME, Sultana J, Sarker SA, Engstrand L, et al. Evidence of intra-familial transmission of Helicobacter pylori by PCR-based RAPD fingerprinting in Bangladesh. Eur J Clin Microbiol Infect Dis. 2009;28(7):767-73.

15. Bonamico M, Strappini PM, Bonci E, Ferri M, Crisogianni M, Guido M, et al. Evaluation of stool antigen test, PCR on ORAL samples and serology for the noninvasive detection of Helicobacter pylori infection in children. Helicobacter. 2004;9(1):69-76.

16. Kignel S, de Almeida Pina F, André EA, Alves Mayer MP, Birman EG. Occurrence of Helicobacter pylori in dental plaque and saliva of dyspeptic patients. Oral Dis. 2005;11(1):17-21.

17. Miyabayashi H, Furihata K, Shimizu T, Ueno I, Akamatsu T. Influence of oral Helicobacter pylori on the success of eradication therapy against gastric Helicobacter pylori. Helicobacter. 2000;5(1):30-7.

18. Rasmussen LT, Labio RW, Gatti LL, Silva LC, Queiroz VF, Smith Mde A, et al. Helicobacter pylori detection in gastric biopsies, saliva and dental plaque of Brazilian dyspeptic patients. Mem Inst Oswaldo Cruz. 2010;105(3):326-30.
19. Silva DG, Stevens RH, Macedo JM, Albano RM, Falabella ME, Veerman EC, et al. Detection of cytotoxin genotypes of Helicobacter pylori in stomach, saliva and dental plaque. Arch Oral Biol. 2009;54(7):684-8.

20. Okada M, Hayashi F, Nagasaka N. Detection of Actinobacillus actinomycetemcomitans and Porphyromonas gingivalis in dental plaque samples from children 2 to 12 years of age. J Clin Periodontol. 2000;27(10):763-8.

21. Fonseca TL, Moraes EP, Juliano CR, Silva AM, Scaini CJ, Mendoza-Sassi RA, et al. Detection of Helicobacter pylori by phenotypic and genotypic methods. Dig Dis Sci. 2010;55(6):1643-8.

22. Scholte GH, van Doorn LJ, Quint WG, Lindeman J. Polymerase chain reaction for the detection of Helicobacter pylori in formaldehyde-sublimate fixed, paraffin-embedded gastric biopsies. Diagn Mol Pathol. 1997;6(4):238-43.

23. Atherton JC, Peek RM Jr, Tham KT, Cover TL, Blaser MJ. Clinical and pathological importance of heterogeneity in $v a c A$, the vacuolating cytotoxin gene of Helicobacter pylori. Gastroenterology. 1997;112(1):92-9.

24. van Doorn LJ, Figueiredo C, Rossau R, Jannes G, van Asbroek M, Sousa JC, et al. Typing of Helicobacter pylori vacA gene and detection of cagA gene by PCR and reverse hybridization. J Clin Microbiol. 1998;36(5):1271-6.

25. Lobo Gatti L, Agostinho Jn F, De Lábio R, Balbo Piason F, Carlos Da Silva L, Fagundez De Queiroz V, et al. Helicobacter pylori and cagA and vacA gene status in children from Brazil with chronic gastritis. Clin Exp Med. 2003;3(3):166-72.

26. Li C, Musich PR, Ha T, Ferguson DA Jr, Patel NR, Chi DS, et al. High prevalence of Helicobacter pylori in saliva demonstrated by a novel PCR assay. J Clin Pathol. 1995;48(7):662-6.

27. Song Q, Lange T, Spahr A, Adler G, Bode G. Characteristic distribution pattern of Helicobacter pylori in dental plaque and saliva detected with nested PCR. J Med Microbiol. 2000;49(4):349-53.

28. Clayton C, Kleanthous K, Tabaqchali S. Detection and identification of Helicobacter pylori by the polymerase chain reaction. J Clin Pathol. 1991;44(6):515-6.

29. Song Q, Haller B, Schmid RM, Adler G, Bode G. Helicobacter pylori in dental plaque: a comparison of different PCR primer sets. Dig Dis Sci. 1999;44(3):47984.

30. Oliveira AG, Santos A, Guerra JB, Rocha GA, Rocha AM, Oliveira CA, et al. babA2- and cagA-positive Helicobacter pylori strains are associated with duodenal ulcer and gastric carcinoma in Brazil. J Clin Microbiol. 2003;41(8):3964-6.

31. de Francesco V, Margiotta M, Zullo A, Hassan C, Valle ND, Burattini O, et al. Primary clarithromycin resistance in Italy assessed on Helicobacter pylori DNA sequences by TaqMan real-time polymerase chain reaction. Aliment Pharmacol Ther. 2006;23(3):429-35.

32. Wang J, Chi DS, Laffan JJ, Li C, Ferguson DA Jr, Litchfield $\mathrm{P}$, et al. Comparison of cytotoxin genotypes of Helicobacter pylori in stomach and saliva. Dig Dis Sci. 2002;47(8):1850-6. 
33. Al Asqah M, Al Hamoudi N, Anil S, Al jebreen A, Alhamoudi WK. Is the presence of Helicobacter pylori in the dental plaque of patients with chronic periodontitis a risk factor for gastric infection? Can J Gastroenterol. 2009;23(3):177-9.

34. Tiwari SK, Khan AA, Ahmed KS, Ali SM, Ahmed I, Habeeb A, et al. Polymerase chain reaction based analysis of the cytotoxin associated gene pathogenicity island of Helicobacter pylori from saliva: an approach for rapid molecular genotyping in relation to disease status. J Gastroenterol Hepatol. 2005;20(10):1560-6.

35. Berroteran A, Perrone M, Correnti M, Cavazza ME, Tombazzi C, Goncalvez R, et al. Detection of Helicobacter pylori DNA in the oral cavity and gastroduodenal system of a Venezuelan population. J Med Microbiol. 2002;51(9):764-70.
36. Li C,Ha T, Ferguson DA Jr, Chi DS, Zhao R, Patel NR, et al. A newly developed PCR assay of $H$. pylori in gastric biopsy, saliva, and feces. Evidence of high prevalence of $H$. pylori in saliva supports oral transmission. Dig Dis Sci. 1996;41(11):2142-9.

37. Blaser MJ. Heterogeneity of Helicobacter pylori. Eur J Gastroenterol Hepatol. 1997;9(1):S3-6; discussion S-7.

38. Souto R, Colombo AP. Detection of Helicobacter pylori by polymerase chain reaction in the subgingival biofilm and saliva of non-dyspeptic periodontal patients. J Periodontol. 2008;79(Suppl 1):S3-7.

39. Loster BW, Majewski SW, Czesnikiewicz-Guzik M, Bielanski W, Pierzchalski P, Konturek SJ. The relationship between the presence of Helicobacter pylori in the oral cavity and gastric in the stomach. J Physiol Pharmacol. 2006;57 Suppl 3:91-100. 